\title{
FROM SLYNESS TO MORAL WISDOM IN THE ERA OF EMERGENT TECHNOLOGIES
}

\author{
I
}

In the beginning there was slyness

The development of humanness in the frame of a wild nature constituted on the basis of objecttive relationships and struggle for existence, and the ontological factor of this development, rarity (Sartre 1960: 200-231), have generated a first trend and, at the same time, a representation of the instrument used by people to survive and resist in the world. This instrument was and was conceived of as their main human quality: slyness ${ }^{1}$.

Indeed, if the surrounding objects seemed to unexpectedly slap them or even hurt them - as if they had been sly superhuman beings - the only pragmatic answer could not be but an inverse slyness, directed from the not yet conscious subject to the dangerous environment.

The ancient goddess of slyness, or cleverness, was $M \eta n-\mu n ́$ being a negation in a hypothetical sense, meaning that the thing one speaks about would be uncertain, presumed, and even inadmissible - and the following words coming from the same root $\mu$ ń show that people have considered, as proof of their ingenious actions, the ability to invent intermediaries between them and nature without which their destiny would have been only to survive through physical effort instinctually organised, but with which their effort is rationally conducted and limited; moreover, cleverness consisted

\footnotetext{
${ }^{1}$ Slyness was a fundamental feature of animals to survive (see also Ford 1999: 272-273). This is the reason that the preferred model of deceptive behaviour was that of beasts. See Machiavelli 1984: Chapter XVIII.
}

in making up tools where the natural forces or laws are not violated but are used so as these tools are artificial manifestations of the natural forces and laws: means to do what nature does "naturally" but with the effort of man; in other words, tools "assume" the physical effort of their creators.

Therefore, cleverness means forcing things and their laws to do by themselves what man would do with difficulty or even could not do at all: in this manner, slyness integrates the artificial (the machines) within the functioning of the human vital forces (Canguilhem a: 87), and just this is the originality of the human life (Canguilhem b: 13). Moreover, Aristotle showed that the first of the four causes is the natural driving one (for example, the natural phenomena as increase and decrease), inherent to nature and acting within the interior of the living. And he added that the artisan does his job by thinking, while nature does it without any deliberation (Aristotle a: II, 1, 630-631).

The words are: $\mu \eta \chi \alpha v \eta \dot{~-~ i n g e n i o u s ~ i n v e n t i o n, ~}$ leading to machine, machine of theatre (Plato), means, expedient, thus slyness,

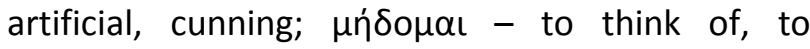
imagine, to invent; $\mu \eta \chi \alpha v \alpha \omega$ - to imagine, to arrange with art, to combine for a purpose, from what to cause, to occasion (and in the negative

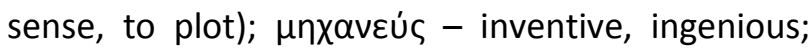

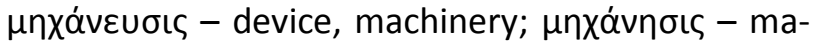
chine, device; $\mu \eta \chi \alpha ́ v \eta \mu \alpha$-ingenious invention, ma-

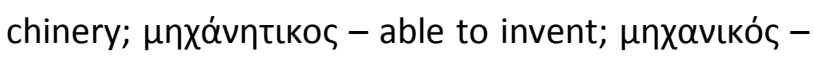


able, hardworking, the art to construct a machine, constructed by the art of a mechanic.

Latin took over these senses: machine-ae; machinari; aliud quiddam machinatur (he intends to do another thing than the one he declares) said $\mathrm{Ci}$ cero, In Verro, 2-15.

But in Greek there is also another word signifying - as people thought to see the logical connection - both the construction/creation by man and

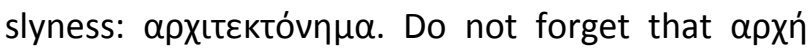
meant what was in the beginning, from where the idea of origin follows. Indeed, what is at the beginning of the human existence than the fact that man constructs? Only by constructing (including as safe shelters as one can), man comes to possess the art or science to understand the things which he rules through construction; $\alpha \rho x \iota \tau \varepsilon \kappa$ tovıkó the architect, the builder, but every person possessing the art or science and thus being able to lead other persons too. See for example $\alpha \rho \chi \iota \tau \varepsilon \kappa \tau \omega v$, the architect, the builder, the technical leader, in oppo-

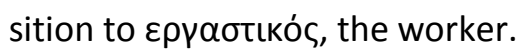

The ontologically determined kinship between the Greek and Latin cultures is illustrated by another Latin word: fabrica-ae means trade, processsing, confectioning, the place where these processses occur, workshop, but also slyness, plot.

Logos is more than slyness

By exercising the sly struggle for living, man has acquired knowledge - art and science, techne and episteme - and a first moment of strain in the process of this acquisition was the spare time in order to examine, to contemplate the world and his own insertion within it. As we know, $\theta \varepsilon \omega \dot{p} n \sigma \iota \varsigma /$ $\theta \varepsilon \omega$ pi $\alpha$ has the same root with $\Theta \varepsilon o ́ s$, or rather its result is the metaphorical personification ${ }^{2}$ of both the image of unique holos where the order (kosmos) and the reason (logos), including the one of the human's, fit together and mutually follow one from another, and the explanation of the general movement of the world. This personification was used by thinkers too: the unity of kosmos and logos, namely wisdom (or named/considered to be "wisdom"), was more rapidly and clearly understood if it was called Zeus ${ }^{3}$.

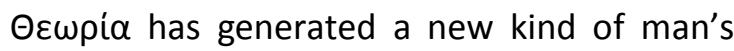
positioning towards existence. While slyness led to a "technical" know-how and to an efficient practical fragmentation of man's vision about his tasks, goals and means (including the separation between the objective world and the subject who did not have another alternative than slyness), the theoretical activity has transposed into the comprehensiveness of the whole. Both comprehensiveness and the idea of the whole have hit the human conscience. The beneficiaries of the social division of labour - physical and intellectual - have called themselves philosophers, those loving wisdom, i.e. those searching for it and considering this search as the highest pleasure of man.

But what did wisdom mean? It was more than a general practical techne, a kind of summa summarum of technical know-how - methodology, principles of concrete problem solving: wisdom referred to the ápxn (the first meaning of the word was beginning, only later on it became principle), to

2 A proof is the Sanskrit origin of God's name, meaning both to invoke and to offer sacrifice (OED: note 8).

3 There is only one supreme Wisdom. It wills and wills not to be called by the name of Zeus". Sources-Clement of Alex. Strom. v. 14, p. 718 (Euseb. P. E. xiii. 13, p. 681). Context:--I know that Plato also bears witness to Heraclitus' writing, "There is only one supreme Wisdom. It wills and wills not to be called by the name of Zeus." And again, "Law is to obey the will of one" (= frag. 110), Heraclitus: 65. 
the ultimate principles and forces constituting and explaining the universe. The explanation of reality is very difficult, one could relate one thing to another ( $\alpha \dot{v} \alpha \lambda o \gamma i \alpha)$ in order to arrive at partial representations of its parts, since we all have the faculty

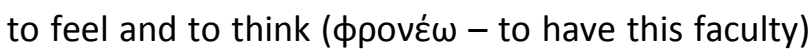
- namely to express articulately our thoughts

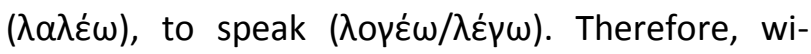
thout palpable proofs and demonstrations, only

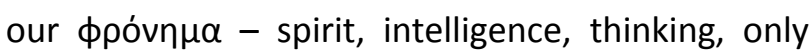
our logical ability to compare those things which are different and separated, only our sparkles of reason are what remains to us. These sparkles allow us to infer - to grasp signs ( $\gamma v \omega \mu \alpha$ - leading to $\gamma v \dot{\mu} \mu \eta$, the faculty to know, judgement, spirit, thinking; the notion being $ү v \omega \dot{\sigma} \sigma \varsigma)$ in order to recognise a thing or another, to separate and to discern (and from here, to choose) (крívw) - thus to use our ability not only to compare but also to detect and avoid contradictions ( $\alpha \dot{v} \tau i \lambda o \gamma i \alpha$ ) and to arrive at conclusions related to a reality of a superior range than that of particular data and premises. Wisdom was not a simple cognisance of these particular data - this cognisance itself ( $\mu \alpha \theta \dot{n} \mu \alpha \tau \alpha$ )

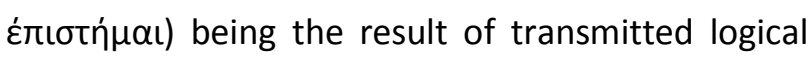
inferences, through discussions referring also to some experiences - but that of the "essence" of things: of their ultimate reasons, principles, constituents, causes, laws of movement and transformation. Even though we all use in a rapid manner the unique word logos in order to describe the ancient representation of the conscience of men concerning their distinctness from animals and their superiority despite their physical weakness, in fact the Greeks have separated the $\lambda$ óyos as everybody's account (saying, words, declaration) or reason, common sense, universal human faculty, from that

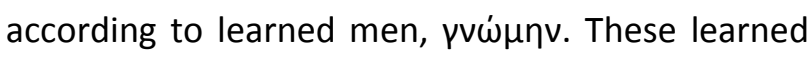
men were not only philosophers, although a "gene- ral philosophical instruction" was a main part of the education of the leading stratum: for example, үvẃбıc meant not only notion, knowledge, action to recognise, but also judicial inquiry or instruction, and thus decision, decree. Briefly, ignorance was not the opposite of logos, but only of the consideration, knowledge and ability to transmit it about the reasons of the whole: apvola.

Therefore, those people who systematically searched for the exercise of logos, thus for the understanding of what this exercise could reveal and in this way arriving at the image of the order of the world and at the possibility to perceive this order with the human reason, thus to integrate within this order - through the correspondence between

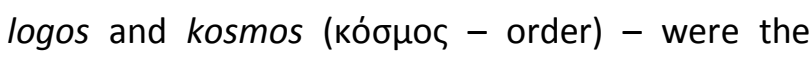
philosophers, in love with the never attained wisdom. Logos which, later on, was named as "the best shared-out thing in the world" (Descartes 1637), should be exercised in order to disclose the laws of the order of the universe, and philosophers were the bearers of this task.

Their importance in the Greek society is related just to the exercise of logos: they publicly shared the knowledge pertaining before only to an individual (the shaman) and, through the word and the no more hieratic writing, they organised the public space (contradictory debates) and supported the birth of citizenship. Indeed, the separation between nature and society means and requires, on the level of mental forms, the manifestation of rational thinking (Vernant 2006: 399-406).

\section{Wisdom and moral wisdom}

One could be tempted to separate and differentiate the "true, objective" content of wisdom like the origin of the world (this origin being philosophically, and no more mythically treated), the 
laws of movement and change, the forces acting and constituting a fundamentally contradictory world, the intuitions of unity, whole and abstract explanatory means and manifestations of unity from the philosophical reference to the human life. In fact, it is not the case ${ }^{4}$, and for three interconnected reasons. First, the correspondence between the universal order which includes man, and his logos required to question and represent the reasons and possibilities of the human action in the same rational manner and at the same high level of conceptualisation (though the forms of this concepttualisation, based on intuitions, seem to be sometimes pre-theoretical, simple). Secondly, because the ancient Greeks never separated the object from the subject as this happened in the later modern manner: neither the object could be understood without positioning the subject within the world, nor the subject could be treated in a philosophical manner as if it had been absolutely exterior to the objective world or explainable in an absolute exterior manner to that used in the explanation of the objective world. And thirdly, because to understand man in a wise manner meant to exceed the collection of practical advices fit for precise practical situations, - a recollection of the necessary slyness to survive inimical events ${ }^{5}$.

Therefore, wisdom is at the same time a moral wisdom. This moral wisdom is not, again, knowledge driving at the arrangement of the behaviour of

4 See a quote from the same Heraclitus, ibid.: "106. It pertains to all men to know themselves and to learn self-control", Source -- Stobaeus Floril. v. 119., and "107. Self-control is the highest virtue, and wisdom is to speak truth and consciously to act according to nature", Source--Stobaeus Floril. iii. 84".

5 Indeed, in the real social life the struggle without mercy for life - that leads even to death/ to agony - was

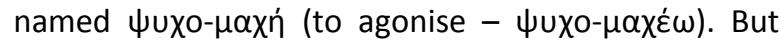
$\alpha \gamma \omega \dot{v} v$ meant fight, while $\mu \alpha \chi \eta$ was military struggle, far more cruel than a simple fight. men and women in accordance with their social status and with the habits and rules of the city. It is the questioning of the human nature and existence and evolution beyond all of these: and even the questioning of the integration of the human being into the universal order and at the same time of the specific of this being.

Wisdom is always moral: not, first of all, because it synthesizes the moral principles - which are general, addressing the human being as such, but which manifest in a historical manner - but because it is public (and not a secret collection of codes and knowledge). It or rather its parts are shared by communities, or are known by their members who reject them. If a cognizance is not, at the same time, a criterion of thinking and action, it could be either a fake element of wisdom or the status of individuals and communities which do not consider it to be problematic. In both cases there is a discrepancy between the bombastic discourses concerning the unchangeable human wisdom that cannot be substituted and, on the other hand, the real ignorance and avoidance of what constitutes the core of moral wisdom: rationality - and its pursuit all the way - and, or thus the idea of interdependence and whole, the dialectics of the individual and the common goods, therefore Protagoras' formula about man who is the measure of all things, man as both the individual and humanity, and as both his objects/objectified results of his action, as science, whose inner logic seems to be more powerful than man's capability to control it, and as subject able to lead the human existence if this subject is always both general and particular, individual and universal.

Wisdom in its philosophical origin is, first of all, the exercise of rationality, of what Descartes named ordro et mensura of scientific universality, of the rules which are not only "strong and right" ( 
Descartes 1908: X, 359), not only "certain and easy" (Ibid., Règle IV, 371 (regulas certas \& faciles)), but constitute science itself. The method (the model of the "universal science") is only an "objective" form of the name of wisdom. But wisdom is, at the same time, humanly controlled rationality or science. If one of these aspects is missing, wisdom rarefies or even disappears.

Finally, let us not idealise the rational content of wisdom. A visible reason of this warning is the difference between the evolution of facts and the tendency of ideas forming wisdom to backward, to be conservative. As a result, we may distinguish a state of already obsolete wisdom - constituted by already accepted, familiar and predictable ideas but which are not necessarily true, forming what Galbraith named conventional wisdom (1998: 6-17) - and a state of what I call dialectic wisdom: ideas surprising the dialectic character of reality and subordinated to the logic of truth (of rational analysis of suppositions and syntheses, of "falsifiability", of change and courage to support non-conformist conclusions).

The conventional wisdom seems to occur rather on the level of ordinary knowledge, but its perspective is usual in science too ${ }^{6}$. Let us remember Thomas Kuhn's "normal science", inherited structures of science, ground for both dogma - an uncritically seen paradigm (Bazac 2012) - and scientific progress.

\section{The experience of life}

Knowledge, thus a bunch of necessary cognisance for a human life - this bunch being wisdom is acquired through experience. This last word is

6 Galbraith, ibid., 9: "with time and aided by the debate, the accepted ideas become increasingly elaborate". obviously revealing the constitution of wisdom. In

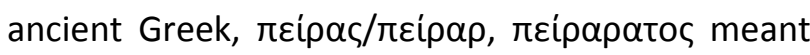
term, limit, end, purpose, the extreme point of a thing, the essential part of a thing, that which gives

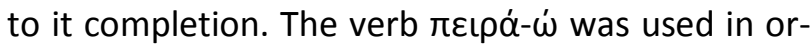
der to describe the effort to force oneself, to tempt another person, to make an experiment on someone, namely to put him/her to the proof, even trying to corrupt, to seduce him/her, to try every-

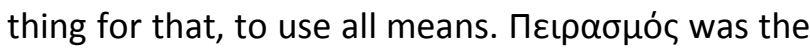
proof, the trial, the experience. Experience appeared as being beyond the usual limits: beyond them there appears something different, of a different essence and status.

In Latin, the idea of term, limit, end ${ }^{7}$ was transposed into the verb pererro - are, to wander through, to cross, to look up and down, to lose one's way. The hardships of life occur after the trips, after the wandering through which one crosses the space. But after this wandering one stops: peritia- ae meant knowledge, ability, talent, and to have all of these one should have a respite to think, to ponder over things, and obviously to act. Therefore, experior- iri- itus sum - to try, to give a trial, to prove, to endure, to take knowledge of or to become aware of something, while experimentum- $i$ was trial, experience, proof, skill; or experientia- ae - test, proof, effort, practice, ability, result, effect, success.

With this significant origin, experience is not only individual or collective knowledge of a unique conjuncture or crossing of events, cultural messages and values, but also a sedimentary knowledge of many conjunctures which form what was called experience of life. This concept coined by Ortega y Gasset (la experiencia de la vida) (1984: I)

7 The Greek origin is the radical $\pi \varepsilon \rho$, and is used in order to suggest the idea of advancing, of tending towards an end, of surpassing the limits one knows. 
was preceded by Dilthey's life-nexus (Lebenszusammenhang) - which insisted on the relation between lived experience and the psychic object (Dilthey 2002: 46-64, 89-90, 218-220, 223-228, 249263) - and Husserl's lifeworld (Lebenswelt), meaning the world of significances (mental and cultural objects) as a result of living together and at the same time being "pre-given" for every individual conscience as an objectified collective subjectivity, "we-subjectivity" (1970: 108-109). For the phenolmenological revolution undertaken by Dilthey ${ }^{8}$ and Husserl, that attacked the presumption of both exteriority of the objective world and from the exterior of this world reflecting conscience of this world, "the lifeworld can be disclosed as a realm of subjective phenomena which have remained 'anonymous'" (Husserl: 111), something almost analogous with Popper's World 2 (1978) if the classification of the Austro-British philosopher would not have been constructed from another (epistemological) standpoint, namely to have in view another philosophical end.

The experience of life - as described by Ortega - is a spontaneous knowledge of life, being a part of life itself and determining its change. It is not the result of a special intellectual effort or of the exercise of reflexivity - as scientific knowledge is - and is constituted within the human conscience automatically, without being the purpose of intentionality. But through this spontaneous knowledge, life as such (thus the lived life) discovers its own reality and this discovery is melting/transposed into life. From all of these and from the fact that the experience of life is irrational, another characteristic follows: that of not being transmittable, transferable from a generation to another.

8 But Dilthey was considered (first by Max Scheler), with Nietzsche and Bergson, as life-philosophers.
We obviously could amend this representtation: as spontaneous as it is, the experience of life is used by the subject with the help of notions and articulated and often metaphorically expressed feelings and images of one's own experience. Thus it is also - and certainly up to a point - transmittable.

But is the experience of life wisdom? It includes, to a great extent, wisdom: at least for language incorporates a long historical experience and its criticism from the standpoint of values and judgement of facts with the instruments of reason. However and as we all can see, the human experiences prove to be for the most part unreasonable and counterproductive, with all the instruments of reason people use or could use. Only according to Ortega's view of experience of life as a general, spontaneous knowledge of life could this concept be superposed to wisdom. But at the same time, if Ortega considers the experience of life as not being transmittable, how could it be wisdom, since this one is just what remains, what could be transmitted and transferred?

Indeed and as Dilthey suggests, life - and the experience of life, obviously - is a vague concept ${ }^{9}$ and the phenomenon of life is known on two levels: the one of natural sciences (Naturwissenschaften), leading to a causal explanation and clarifycation of the relationships between general and particular and having an abstract relation with life (as an exterior observer), and the one of human sciences (Geisteswissenschaften), intending only to understand the relationships between the whole and its parts and thus focusing just on life, but from the inside. This is the reason of different trajectories and evolution of the experiences related to these differrent sciences.

\footnotetext{
$9 \mathrm{AB}$, moreover as wisdom is too.
} 
Thus, scientific experience is: a) deliberate and $b$ ) has expected effects (confirming these ones, or not, the presumptions of experience), c) is chosen by the scientist from an exterior, "objective" world, d) and is oriented toward this world, e) in the same framework of data is repeatable; but neither the scientific experience is really repeatable (each scientific experience is new, i.e. being based on new features chosen from the objective reality), f) but it can be transmitted; in sum the world reproduced by science could be known in terms of truth, objectivity, certainty, reliability. This world supplies many features to Weltanschauung, to worldviews having the role of criteria of good or at least productive human behaviours. While the experience of life is: a) formed by/resulting from both intentional and non-intentional manifestations of life $\left.{ }^{10}, b\right)$ is oriented toward the self, c) aiming at interpreting the relationships between whole and its parts, d) there are not identical frameworks that might allow the repetition of different experiences of life, e) the possibility to transmit the experience of life is limited to and by the perspectives of interpreting it. The world is thus rather life which appears as a kaleidoscope, in multiple lights or shadows of interpretations generated by different positions in different contexts. People could, obviously, consider delusive interpretations as criteria of human safety, but do these interpretations constitute wisdom?

A key of the understanding of the experience of life is the existentialist concept of situation ${ }^{11}$. It emphasises complexes of factors bunched in a

10 Dilthey 2002: 226: "those that without any such intent to express spirit nevertheless make it understandable. Understanding will differ in kind and scope in relation to different classes of manifestations of life".

11 This concept was developed by Sartre already in Being and Nothingness (1943). For recent interpretations, see Ana Bazac, 2008, 2010. unique manner. But it may be transmitted between individuals and from individuals to communities and vice-versa.

Therefore, the experiences of life do sediment, generating wisdom as a synthetic processing and processed knowledge. and the gentleness of wisdom

The comparison between science/scientific experience and a general, moral experience of life is fruitful from the standpoint of the subject leading/taking part in these different experiences. In science, the subject is the expert having precise and high competence in a specific realm. The expert is not only the creator of this realm as such - of theories, experiments, tests, analyses, critiques - but also the most authorised voice in front of the public.

The expert is a scientist, i.e. possessing a clear and systematic cognisance in the field he works. He knows, comparatively to those who are not experts, but only dilletanti or laymen. And how does this expertise manifest itself first of all? To understand this, let us take this time a critique of art: he/she is obviously an expert in painting. He/she is called to settle the worth of a painting. At first glance he/she knows the school the piece belongs to, if it is about something valuable or an amateur copy etc ${ }^{12}$. Certainly, more specific analyses follow, with specific technology, but this first general glance is essential and summarises an entire knowledge and professional experience: it is a professsionnal "intuition"13. The same is with a scientist or a philosopher. In the common language the expression: "it's enough to open his/her mouth for we know what is his/her worth or if he/she has, or not at all, the worth of an expert" synthesises this aspect. Expertise is the name of scientific or profes-

12 See the behaviour of the critique of art in Agatha Christie's After the Funeral (1953).

13 Dreyfus and Dreyfus, 1980; Dreyfus and Dreyfus, 1986: 101-121. 
sional "wisdom", if we use this word metaphorically for knowledge. Knowledge is the basis of the further development of science, action, creation, and it is not important here that the human reason and capability to contain and process information is limited $^{14}$.

But what happens in what we mentioned as experience of life, or in the moral behaviour of people? Do common people have some knowledge related to this behaviour? They certainly have: from the vast experience of life they possess through stories about moral behaviour of so many historical and particular examples - and not only from their own life - they learned values, profitable reactions, the importance of impressions people are able to give, an entire dialectics of truth and lie and so on. This wisdom of life is the result of and reflects what the Romanian philosopher Lucian Blaga called "the cultural style" - a structure of manners to think, as both technical methods of inference and horizons and limits of notions, a "stylistic matrix" with its "abyssal categories" - which is moulding upon the historical human being and leads its development, i.e. the cultural creation; or in other words, wisdom comes from what Carl Gustav Jung understood as "archetypes", representations/motifs derived from the archaic collective unconsciousness.

As we know, this moral knowledge is ideological, namely depends on the social position of people, either of their own position or of another they nevertheless support: "ideology structures the social reality itself" (Zizek 2009: 30) and we cannot understand human behaviour if we rely only on the tenet of rationality (that meaning also irrationality and unconsciousness). But as ideological as it is, moral knowledge - and we could call it moral wis-

14 See the vast literature supporting the superiority of the expertise of Artificial Intelligence (Al) toward the human expert. dom - exists. People "know"/feel, though they cannot express the complexity of each situation, correctness or incorrectness, cheating, treachery. The fact that this knowing is covered up by the logic of power - i.e. of the domination-submission relations - is real, and the removing of ideological veils covering people's moral wisdom is difficult (being at the same time the most valuable content of social theory ${ }^{15}$ ), but all of these do not annul human sensitivity (namely, the ability to judge things according to reason and values) in front of human action and facts.

Man has, simultaneously, superposed and overlapping states. He may simultaneously act in moral and immoral manners. People who observe and judge are clever enough to feel that "something is wrong" with a person or another. This is moral wisdom. The fact that people could act in an opposite way to their moral wisdom, that they could - by mixing conscience and unconsciousness - benumb, even annihilate their moral wisdom, does not annul their moral sensitivity/capability. This fact draws attention, however, to the correspondence between the directions of thinking of scientists in ethics and, on the other hand, the common behaviour. According to some, not the moral notions and feelings would be essential in order to act as a human person, but the empiricism of situations where the individual should manage. An excessive result of this position is the present trend of arbitrariness, carpe diem principle and egotism. Other theorists - as well as ordinary people who are confident in principles - warn that we should never forget moral wisdom.

If so, let us finish this part with the observation about the gentleness of wisdom. Indeed, both

15 See, for example, William L. McBride (2001) speaking about global injustices and the values that remain after these injustices at the level of common people as well as of thinkers. 
scientific knowledge and moral wisdom should have a kind of naïveté, i.e. trust in the possibility of knowledge - obviously in junction with the conscience of relativity and failing character of cognisance - namely, in the openness of horizons it constitutes. This naïveté is not simplicity resulting from ignorance or artlessness, but rather it is synonymous with trust, specific only to the rational human being. Man, confident in his possibility to know and in the liberating character of knowledge is the human already exercising his rational capabilities: therefore, naïveté is not the consequence of inexperience of the responsibility of knowledge and rational action but on the contrary, the sign of familiarity with this responsibility and rational action.

Wisdom is thus gentle in the sense that it presupposes trust. But trust means and requires mutuality: i.e. if people using wisdom do not manage it in a constructive and creative manner, it becomes obsolete and rather brakes knowledge and human development.

II

\section{Wisdom and society}

In order to surpass a metaphysical approach focusing on the concept and deducing from it how the world should be, we have to change the view. If we start from the global problems which are graver in the manner of an avalanche, we may immediately conclude that people at world level prove to be devoid of wisdom. With all the intellectual instruments they possess and with all the scientific discoveries, people act as if they knew nothing about these problems, as if they did not manage the intellectual instruments and scientific discoveries at all, and as if they absolutely lacked both freedom to think and act and responsibility.
The main cause of this fact is, however, not intellectual but social. The power relations which prevent indeed the majority of humankind from manifesting their freedom and responsibility at a large scale ${ }^{16}$, generate the priority to fulfil the interests of the powerful in spite of the interests of humanity as such.

A feature supporting this fact is the management of knowledge. From this standpoint, one may observe the contradistinction between the fragmented wisdom - of the individual, of "my community", of a certain community, be it smaller or larger -and the global problems. In any case, the global result of this contradiction is disastrous, and suggests that wisdom - the immaterial power people are so proud of - would be only a vulgar slyness.

But wisdom is not only "know-how", concrete problem solving, but also - or rather first of all - a set of principles of methodology in order to solve problems globally and at the same level of efficiency. The reason of the opposed situation to this elementary requirement is that problem solving was, historically, fragmented. The fragmented character of problem solving is an ontological datum.

As it is commonly understood as the necessary cognisance in order to survive and live comfortably, wisdom could surely suppose parochial, fragmented perspectives and slyness within and by pursuing egotist aims. These characteristics are visible in both the public behaviour of the political class (Oborne 2007: 3-6, 123-124) and quite many ordinary people - who all act even against the moral principles already assumed: no one assumes publicly that it would be better to be a thief, a prac-

16 Otherwise, people have freedom at a small scale, i.e. related to their actions inside the given and unflinching power relations. 
titioner of plagiary etc., but they act in this manner - and in some directions of scientific development/of financing scientific and technological development (for example, those subordinated to private interests even at the expense of ecological destruction or agricultural unbalance).

Regardless of this last fact, in their historical evolution, science and technology were fragmented. Only philosophy was preoccupied with the whole, consisting fundamentally in holistic directions. As science which was the consequence of both curiosity and spirit of problem solving, philosophy resulted in the same manner and both went from appearance to essence (though science touches essence leading to causes). Wisdom was what was given by this historical evolution.

But did really science and technology lead to wisdom? According to Jean-Jacques Rousseau, the answer is negative and thus pessimistic. The human relations and the moral values they are based on were far more backward than the modern spring of sciences (Rousseau 1866: 466).

The present state of things may be described as absurd ${ }^{17}$ : if every human being has the logos, he/she could be wiser or less wise and, secondly, he/she benefits au fond from the wisdom humanity won through the length of time and possesses nowadays, but at the same time, policies all over the world are so irrational and have so harmful consequences for the human community as a whole and for the unique and unrepeatable persons forming its majority, that the abstract conclusion regarding wisdom is seriously jolted.

If we consider the ecological crisis, the economical crisis, the spiral of violence and warfare, all the aspects of these scourges, we arrive at the sa-

17 The absurd is the difference between the image about us and the world and, on the other hand, reality. I defined the absurd in my 2010 paper, based on Camus 1943. me conclusion already suggested here: they cannot be radically solved (worldwide and at the same time in every country) in the old frameworks of welfare state or local self-sufficiency, just for these frameworks are fragmented. We do not yet know what and how to change and do, but it is already clear that the old methods do no longer work. These methods have led to a "liquid" wisdom, if we may take over the attribute of late modernity described by Bauman (2000).

A concluding remark is that, as science (Bazac a, 2013), wisdom should be considered as a common good of humanity, freely shared and accessed by every community and human being, by the world as a whole. This means, first of all, free access to the rational and cultural instruments: to the exercise of reflexivity, to the analytical/critical spirit, to the holistic approach, to information.

The spring of science and the expectations of the formidable technologies

There is a big difference between technological and scientific discoveries. Voltaire writes that the most important inventions - the use of fire, the art to make bread, to melt and process metals, to build houses, the use of shuttle - have occurred much before scientific discoveries, being contemporary to a very barbarian state of knowledge (1778: Letter XII).

The first modern industrial revolution was so impetuous that, as Stefan Zweig has noted (1942), a big part of the Western population (and especially its intelligentsia) was convinced even some years before the First World War that modern civilisation has already left behind a primitive animosity and warfare.

In this framework, it is necessary to remember Heidegger's questioning of technology (1982) - as 
the dominant figure of the present - and relate it to some present aspects (as the development of gadgets, the "hostility" of machines (Lafargue 2011), the dependency on technology, symbiosis and antagonism between man and technology (Hancock 2009): briefly, to criticize techno-science as the last bastion of a messianic hope in a secularised society (Postman 2001).

After the Second World War, the new industrial revolution based on IT has generated a high degree of trust. (In 1999, 89\% of Americans believed that the current level of the science and technology fields will bring about a substantial and general improvement to life, while in 1996 only $77 \%$ held this opinion. $55 \%$ of Americans were convinced that the inconveniences are negligible when compared with the benefits of the IT and, thus, it is legitimate to rely completely on science and technology. Only $39 \%$ of the respondents have objected to the fact that such a situation could make people much too dependent on technology and sometimes making life too complicated) (A Future 1999).

The present era is marked by an accelerated level of scientific discoveries, and as these ones are implemented and generalised, the price of technological products decreases: so that the high access configures a more and more democratic civilisation ${ }^{18}$ with more and more peaceful manners and human intertwining. Is it really the case? We witness the contradictory development of society (Chang 2010) and its causes, thus neither the fully optimistic nor the pessimistic viewpoint are sustainable.

${ }^{18}$ I use this word as a state and process of generalisation of material creations in the framework of social institutions.
Wisdom and technology

In the spectacle of the present society, appearance is what hits us with a strange force. It seems that the whole wisdom has concentrated in things. Almost all things surrounding us are made by technology.

These things have their autonomous life, as if every one would contain a spirit (or would be the glass bottle containing the spirit, or Aladdin's lamp). But this means that, at the same time, these things are superior to man who, humbly, feels a "Promethean shame" that he/she is so limited in coporeal force and mind cleverness in front of the perfection of machines. This shame is the result of the "Promethean slope", the late modernity inverting the original relationship between man and technology: while in the beginning, the human mind was the source of objects and human survival, the model being the cleverness of Prometheus discovering the fire, at the same time the tools and musical instruments needing man's touch and power $^{19}$, late modernity witnesses the huge power of automate machines and its independence from man, the use of Atomic bomb at Hiroshima and $\mathrm{Na}$ gasaki being the irreversible sign of this slope: man being far from that time onwards able to destroy himself (Anders 1981: 96; Anders 2002: 266, 294). In fact this shows that man is not free toward technology which accentuates the fragmented and atomised spirit, morally indifferent and egotistic.

19 Aristotle b, Book one, part IV, p. 2794: "For if every instrument could accomplish its own work, obeying or anticipating the will of others, like the statues of Daedalus, or the tripods of Hephaestus, which, says the poet, of their own accord entered the assembly of the Gods; if, in like manner, the shuttle would weave and the plectrum touch the lyre without a hand to guide them, chief workmen would not want servants, nor masters slaves". 
Indeed, the autonomous life of technology is unforeseeable: it follows its own logic - if something can be done, it will be so, as the representatives (or "sponsors") of the theory of engineered singularity underlined (Bazac 2011; Bazac c 2013), irrespective of its consequences. But, since technology supposes the subject-object relationship, which is obvious if we put the question "technology for whom?", it has to promote human wisdom, namely suitable for man, not damaging him. My insistence on the subject-object relationship contained by technology does not aim at subordinating in an abstract manner technology to man: for, indeed, man's performances are weaker than those of technology; but only at subordinating technology to the rational and public debates concerning the values, the motifs and reasons conducting the development of technology. Since the human being constitutes itself through dialogue, technology too has to be subordinated to ethical argumentation/ to the progress of discursive rationality. But this does not mean braking the logic and internal capabilities of technology: this would be a stop from a conservative, regressive standpoint; but only to supply it with social space of development in favour of man.

A first example is biomedical engineering. The last 20 years witnessed an almost new medicine with the help of biomedical engineering. Hope expanded as time passed, since every moment the news announces a new procedure that could lengthen life and soothe pain. In fact, there is a gap between the technical possibility to cure (and the rhythm of this possibility) and the social limits.

An aspect is the industrialisation of health care subordinated to the logic of private profit. Ivan Illich (2010) showed that the result of the industrialization of health care is pain and sickness, and restricts the vital autonomy of people. This result is thus iatrogenesis: the transformation of man into a dependent being and, at the same time, impregnated by illness induced just by industrialized medicine and pharmacy. This is a social phenomenon generated not by the mere logic of medical discoveries, but one of the social frameworks these discoveries take place within: "iatrogenesis cannot be understood unless it is seen as the specifically medical manifestation of specific counterproductivity. Specific or paradoxical counterproductivity is a negative social indicator for a diseconomy which remains locked within the system that produces it... The recovery from a society-wide iatrogenic disease is a political task, not a professional one" (alone) (ibid.: 8, 6; Illich 2002).

Another aspect requires a revisiting of the optimism nurtured by the Western style medicine. There is an excellent criticism of this style and its counter position to the Oriental medicine (Pignarre 2005). Then professional analyses put in evidence that "better sanitation, better housing, better diet played the biggest role, while vaccines, drugs etc, only a small role in the rise of life expectancy in industrialised countries from $\sim 35$ to $\sim 75$ years over the last 250 years.

Medical intervention has contributed little to the decline in mortality - one major US study concluded probably as little as 3,5\%". Moreover, "technological development has led to exponential growth in lethality during $20^{\text {th }}$ century" (Parkinson 2010).

The second example is food and agricultural engineering. Nowadays there are agricultural techniques which have a huge productivity even without using chemical stimulants, cloned animals and subjected to growth hormones, genetically engineered seeds and cultures marked by herbicide glyphosate (Berlan I; Berlan II). The biological and agricultural sciences are so developed that now we 
know what to do for having a healthy food and life. We know in which proportions the very processed food, the artificial substitutes and simulacra of necessary matter to eat are dangerous to us. We know the proportions of fat, glucoses, carbohydrates we need or, on the contrary, which are dangerous to us. We know how much to eat without harming us.

We also know how to care of the land/earth, in length and depth.

But we face a chaotic world where, in the second decade of the third millennium, millions of people who are overweight live near millions who are undernourished (Izambert 2009: according to the UN agencies, every 4 seconds a human person dies of hunger (and not in epidemics or wars). We speak about famine and hunger, even after nearly 70 years from the Second World War ${ }^{20}$, and obesity is not necessarily related to the waste of food, rather to the malnourished situation of the poor (working poor) and impoverished middle classes (as well as to the unhealthy way of living, as sedentary or excessive regime of work). But the food waste ${ }^{21}$

20 Ziegler, 2011: 14; almost one third of the 56 millions of civil and military deaths in the Second World War were caused by hunger and its immediate consequences; in 1942-43, a half of the population of Bielorrussia died of hunger, and in Poland and Norway many died from the same cause.

${ }^{21}$ Gustavsson et al. 2011: one-third of the food produced for human consumption is lost or wasted globally, which amounts to about 1.3 billion tons per year; Overall, on a per-capita basis, much more food is wasted in the industrialized world than in developing countries... the per capita food waste by consumers in Europe and North-America is $95-115 \mathrm{~kg} /$ year, while this figure in Sub-Saharan Africa and South/ Southeast Asia is only 6$11 \mathrm{~kg} /$ year; The causes of food losses and waste in lowincome countries are mainly connected to financial, managerial and technical limitations in harvesting techniques, storage and cooling facilities in difficult climatic conditions, infrastructure, packaging and marketing systems; The causes of food losses and waste in medium/high-income countries mainly relate to unites with the production of an enormous quanity of unhealthy, artificial food, promoted by an aggressive advertisement. Imagine the enormous energy, creativity and material expenditures used for this production. Do they not waste the energy and matter of the production of a healthy food?

If it seems that there would not be sufficient money to invest in agriculture and food industry, but, according to SIPRI - Stockholm, at the same time the military and armament expenditures are so high $^{22}$, we have to question the rationality of this repartition of expenditures. Is the military-industrial complex (http//:wiki... 2014) right when pressing for the increase of the military expenditures, or every ordinary man and woman, people in general, when reclaiming the right highlighted by FAO, their right to a healthy food (http://www.fao... 2014):

Therefore, there is both a cognitive dissonance between all these aspects and a tendency to reduce the discomfort of some of the previously mentioned evidences. Indeed, in order to alleviate this dissonance, some theorists advance the thesis of a "natural" food crisis.

\section{Emerging technologies as a tool of human expectations}

Emerging technologies (information technology, nano and biotechnology, robotics and artificial intelligence (AI)) are those which, irrespective of their conditioning by the competitive advantage, originate especially in the new scientific revolution

consumer behaviour as well as to a lack of coordination between differrent actors in the supply chain.

22 SIPRI 2011: "World military expenditure is estimated to have been $\$ 1630$ billion in 2010-a real-terms increase of 1.3 per cent over 2008 and of 50 per cent since 2001. This corresponded to 2.6 per cent of world gross domestic product (GDP) and $\$ 236$ for each person in the world". 
of micro-electronics, biochemistry and convergence and inter-disciplinarity of these sciences in the last about 40 years or even only 25 . The specific of emerging technologies is their close relation with sciences and the new epistemological approaches as holism, inter and trans-disciplinarity.

At the same time, emerging technologies illustrate the logic of science and technology at this new stage: the accelerated rhythm of technological implementation of scientific discoveries. But this trend of returns of the acceleration of scientific and technological discoveries (Kurzweil 2001) is "translated" by the social constraints it functions within. This "translation" is supported by the mainstream ideology: the returns are conceived of as aiming at the increase of consumption and profits, all the human values being subordinated to the implicit reasoning that if something is bought, then it will be beneficial. As we can see, the fragmented manner of thinking is obvious in this supposition.

The technophile perspective was constitutive of the liberal ideology of the first industrial revolution and development of Western capitalism. The same view accompanies the present industrial revolution (the fact that this revolution is contemporary with neo-liberalism - as it is called in Europe - or neo-conservatism, as it is called in America, is not important here; the technophile support of some intellectuals in this era of neo-liberalism shows only the ideological confusion, the moral opportunism and the traditional education of intellectuals to stand outside the questioning of social and political rationality).

Indeed, in this view the spring of technologies will eliminate poverty and famine - but it does not say a word about the elimination of war $^{23}-$. The

${ }^{23}$ But the lucid economist Georgescu-Roegen, 1975 - who was not a Marxist - wrote that from the standpoint of power economy, "the production of all instruments of first remark here is that social problems are considered in this view in the same fragmented manner as before the present industrial revolution: because today it is already obvious that "act locally" is no more sufficient and is ineffective; neither ecological problems nor the world problems of war, labour, education and human rights can be solved by means of fragmented policies aiming at answering the more urgent shortages of a local community that should support the local politicians' credibility.

The second remark is that technophilia or techno-utopianism is techno deterministic, namely it considers that there would be a single determining factor, science-technology, and that social change would result uniquely from this factor. Social determinism - classes and class interests, power and ideology - does not exist here. (Opposite to this liberal view was that of Karl Marx who combined the two lines of determinism). This is the reason of perhaps involuntary bitter suggestions about the inevitability of the destructive trends of humanity through the development of scientific and technological findings, already existing in the 70 s of the last century (Kahn and Wiener 1967).

The third remark is that, ultimately, not even the technophile supporters of emerging technologies are optimistic. A powerful example is transhumanism and singularitarianism, the ideology of the coming artificial rational being (with brain of $\mathrm{Al}$ ) substituting man. As I showed (Bazac 2011, note 49), the technophilia of this view is only apparent: in fact, according to Al supporters, the global problems will be solved only after the substitution of man by Al.

Further on, with the present alert rhythm of all emerging technologies the global problems do not even alleviate: as we can see, tensions and

war, not only of war itself, should be prohibited completely". 
warfare, famine and food and water crisis, environment crisis, the lack of sense/reason of life expand, overwhelming the world. The fundamental cause of the global problems is not technological, but social, and they cannot be solved by technological improvements here and there.

The replication of technology is predictable. If one does not give full play to anticipation and predictability, it is because of non-technological reasons. The framework created by these reasons has damaging consequences for the lives of millions of human persons. And the ability of these persons to understand the real stakes of the social facts and political decisions is weakened by the media which inject scepticism toward the warnings of scientists (Boykoff 2011), but also by a handful of professionals who stir doubt concerning scientific data and facts (Oreskes \& Conway 2011).

Consequently, the problem of wisdom faces, obviously, new challenges given by emerging technologies: and from this point of view the analyses about wisdom refine the old representations. But, at the same time, the novelty promoted by emerging technologies does not substitute the philosophical inquiry into man, conscience, society, knowledge and responsibility.

Could we talk about human wisdom?

In front of this reality, the human conscience seems to be overtaken: it is by far lagging behind; it cannot manage reality in a rational manner and is only the ground of cognitive dissonance. All the beautiful words about wisdom seem superfluous. In fact, this is not the only conclusion we can draw. Things are always complex: and a reason of the previously mentioned backwardness of the human conscience is just the inertia of technophilia ${ }^{24}$ and the dominance of the uncritical ideology of domination. Or, more clearly, to the inertial ideology of domination, inertial and simplified ordinary patterns of thinking correspond. Briefly, people could be wise, but they are stopped and refrained from the exercise of reason by power relations, more precisely by the domination - submission relations.

Power relations - more and more unnecessary for the human development ${ }^{25}$ - constitute the constitutive factor of a certain majority of social behaviours. These ones seem to be only sly, and not rational. Perhaps, at the private level - or that of the oikos, the household (Arendt 1958: 28-37) many people seem to have internalised wisdom, since their actions are efficient; but, beyond the retort that this efficiency in order to acquire the means to live comfortably, or at least not to starve, is rather the result of slyness, all of these separated efficient behaviours generate an irrational public life and state of the world. The inertia of power relations has led to the fact that the present days do not witness at all a passage from slyness to wisdom, but rather the weakening of reason, the rarefying of wisdom and the emergence of an irrational world that cannot be managed: the emergence of "barbarity", as some unpractical and critical dreamers used this last word quite long ago.

Therefore, to pass from slyness to wisdom would be rather a conclusion and desire of theo-

${ }^{24}$ By the way, we have to observe the fundamental consensus and convergence between the theories of mainstream ideology (mainstream is opposed to critical theory): for example, between the technological optimism and the present global justice theory (Thomas Pogge) of donations from "giving what we can" (Giving What We Can is Thomas Pogge's NGO promoting the principle of donations "at least", i.e. of the individuals and groups which compensate through their behaviour for the unjust institutions (to which they themselves contribute). See Bazac b, 2013.

25 But the power relations were necessary so long as rarity was the ontological factor of society. 
rists, than a characteristic of the present society. But if so, theorists themselves have to become preoccupied with human strategies: with "what to be done", in order to change this state of things.

Wisdom is negated when human beings are hungry and when children and people die of curable diseases. The first leap toward the overthrowing of this situation is pity and help. But if these ones are fragmented, they have a hypocritical significance. With a deep sorrow, the second leap is indignation: if the concrete consideration of the others - manifested through explicit social organisation and relations - is missing, and if the lack of human conditions and future substitutes the opportunities, people are far from the situation to demonstrate their human dignity. And if they are not dignified, if others do no longer consider them as worthy of representing human dignity, they become indignant at this condition: in Latin, in + dignatio means just the opposite situation to dignity, and the awareness of the situation where the others do no more treat a person with respect for his/her humanity, but treat him/her indigne - unjustly, with cruelty, shamefully.

These leaps are accompanied by the jolting of conscience: if I am so precious because I am a unique human person, the others are precious and $u$ nique too; and if it is the case, my search for the joy of life depends on the search for the joy of life by the others. My self-esteem, grounded on my rationality, supposes my capacity to avoid my personal fault related to the waste of creativity and life of the others. But they have the same wisdom: thus, a wise human life is possible to all of us. This life involves friendship (amicalité), openness to the world, without possession and appropriation, and "poeticallity" (poéticité), poetically living the relationship with the world (Lauxerois 2010).
The poetic manner to live life is, certainly, a metaphor for a creative life, lived in dignity: thus taking over and bringing human wisdom further. Heidegger said that living poetically means measuring the space between "the sky" - the ideal, never ending, shadowed or unknown but at the same time suggesting infinite possibilities - and "the earth", the concrete praxis for the real needs. The essence of man is just "to dwell in a poetical manner" (Heidegger 2003), namely to always be worried about his ideal criteria and to always measure "the dimension" between the ideal and the world of necessity. "When this measuring appropriately comes to light, man creates poetry from the very nature of the poetic. When the poetic appropriately comes to light, then man dwells humanly on the earth" (ibid.: 278).

What a beautiful metaphor and metaphorrical expression of a creative, thus conducted by the human rationality life! But how many people are estranged from this life! And how strong are the policies and the deliberate actions of some people leading to this life!

$$
\begin{aligned}
& \text { Instead of conclusions: we have to focus } \\
& \text { on more than wisdom }
\end{aligned}
$$

Wisdom, as rationality, suggests a main and many times forgotten characteristic of both man and the realm of philosophy: universality. Possibly pertaining to all human beings, wisdom is universal, and it has to be studied in the key of universality. As we know, no concept - thus not even universality - is the ultimate $\alpha \rho x \eta$ or centre of the interest of thinking. For example, ecumenism as ideology of the unity of Christian churches, or better, interfaith dialogue in order to realise a religious unity of the world are historical forms of the idea of universality and promote it. And in the present world, where 
the fragmented views are so strong and the dissolution of particular solidarities so obvious, many people think that the only proof of human universality would be the religious one. It is not the case, certainly, but the above-mentioned view warns us to consider universality with the same epistemological prudence.

However, we all need the key of universality, and it is fundamental to a critical attitude toward society and man. What we have to try is to concretise universality in the most human and efficient sense.

Attempts of concretisation are, from the standpoint of the analysis of wisdom, notions such as the intolerable and the irreparable. Indeed, these notions are important not only in relation with the avoiding of the personal fault and the justification of the personal expectations of the joy of

\section{REFERENCES}

1. Anders, G. (1956). L'obsolescence de l'homme. Sur l'âme à l'époque de la deuxième révolution industrielle (2002 trad. fr. Ch.David). Paris: Éditions de l'Encyclopédie des Nuisances/ Ivréa.

2. Anders, G. (1981). Die atomare Drohung. Radikale Überlegungen zum atomaren Zeitalter (2003), München: Beck.

3. Arendt, H. (1958). The Human Condition. Chicago: University of Chicago Press.

4. Aristotle (1925). "Physics", II, 1, Translated by R.Hardie and R.Gaye, in: Organon, Edited by W.Ross, Clarendon Press, Oxford, pp. 630-631.

5. Aristotle (1925). Politics, I, translated by Benjamin Jowett, in: Organon, Edited by W.Ross, Clarendon Press, Oxford, p. 794. life - thus the criticism of those who oppose this joy - but, rather, just in relation to society as a whole, to its mechanisms and judgements about them. The concepts of intolerable, irreparable and of the feeling of irreparable, as well as of deep sorrow, and of indignation and of reformist spirit could preoccupy us when we try to understand human wisdom in front of its hardships.

It is not the place to analyse these notions. Suffice to say here that when people act indifferent to the intolerable consequences of these actions regarding society as a whole and many unique and unrepeatable individuals, neither they nor the views they represent prove wisdom. Therefore, the focus on wisdom is not so neutral and abstract as it could seem to be: it rather challenges us to act more philosophically and think more politically involved.

6. Bauman, Z. (2000). Liquid modernity. Cambridge, UK: Polity Press.

7. Bazac, A. (2008). "Sartre and the responsibility of choice". Revue roumaine de philosophie, 1-2, pp. 173-185.

8. Bazac, A. (2010). "La révolte et la lutte: Albert Camus et Jean-Paul Sartre en dedans et en dehors de l'existentialisme". Revue roumaine de philosophie, 2, pp. 239-266.

9. Bazac, A. (2011). "Between aspiration and model: the social construct of the future man". In Proceedings of 2011 IEEE International Conference on Grey Systems and Intelligent Services (GSIS), $15^{\text {th }}$ WOSC International Congress on Cybernetics and Systems, Editor-in-chief Sifeng Liu, CD, Nanjing University, pp. 932-937.

10. Bazac, A. (2012). "Lucian Blaga and Thomas Kuhn: The Dogmatic Aeon and the Essential Tension". №esis, XXXVII, pp. 23-36. 
11. Bazac, A. (2013). "The worth of man on the threshold of his technological transformation". In: Values of the Human Person: Contemporary challenges, Editor Mihaela Pop, Romanian Philosophical Studies, VIII, (Cultural heritage and Contemporary Change, Series IVA. Eastern and Central European Philosophical Studies, Volume 47, General editor George F.McLean, Washington D.C, The University of Bucharest, The Council for Research in Values and Philosophy, Washington D.C., pp. 221-240.

12. Bazac, A. (2013). "Citoyenneté et biens communs de la science". Analele Universității din Craiova, Seria Filosofie, no. 32, (2), pp. 105-129.

13. Bazac, A. (2013). "Global injustice: what is known, what is assumed and what is promised?", Studia UBB, Philosophia, 58, No. 2. pp. $145-157$.

14. Berlan, J.-P. (I): “Derrière les OGM, c'est un projet de mort qui s'impose," https://gro ups.google.com/forum/\#!msg/mediasmens ongesdesinformation/Qo3MtUX8r3g/V3fw NjEOkewJ (accessed May 20, 2014).

15. Berlan, J-P. (II) : "Il faut réinventer le contraire du monde dans lequel nous sommes," http://www.bing.com/search?q=Berlan \%2C+JeanPierre.+\%28II\%29+\%3A+\%E2\%80 \%9Cll+faut+r\%C3\%A9inventer+le+contraire + du+monde+dans+lequel+nous+sommes\&f orm=UP97DF\&pc=UP97 (accessed May 20, 2014).

16. Boykoff, J. (January 30, 2011). "Reheating the climate change story". http://www.gu ardian.co.uk/commentisfree/cifamerica/20 11/jan/30/climate-change-climate-changescepticism (accessed May 15, 2014).
17. Camus, A. (1942). Le mythe de Sisyphe. Essai sur l'absurde (édition augmentée 1943). Paris: Gallimard.

18. Canguilhem, G. (1952). "Aspects du vitalisme." In Canguilhem, G. La connaissance de la vie, Paris: Vrin.

19. Canguilhem, G. (1952), "La pensée et le vivant". In Canguilhem, G. La connaissance de la vie. Paris: Vrin.

20. Chang, H.-J. (2010). 23 Things They Don't Tell You About Capitalism. New York Bloommsbury Press.

21. Descartes, R. (1626-1628). "Règles pour la direction de l'esprit (Regulae ad directionem ingenii)." In René Descartes, Oeuvres Volume X_(Édition Charles Adam et Paul Tannery, Paris : Léopold Cerf, 1908).

22. Descartes, R. (1637). Discourse on the method of Rightly Conducting the Reason and Seeking for Truth in the Sciences, https:// www.marxists.org/reference/subject/philo sophy/works/fr/descarte.htm (accessed May 9, 2014).

23. Dilthey, W. (1910). Selected Works, Volume III: "The Formation of the Historical World in the Human Sciences". (Edited with an introduction by Rudolf $A$. Makkreel and Frithjof Rodi, Princeton and Oxford: Princeton University Press, 2002).

24. Dreyfus, S. E. and Dreyfus H. (February 1980). A Five-Stage Model of the Mental Activities Involved in Directed Skill Acquisition, http://www.dtic.mil/cgibin/GetTRDoc ?AD=ADA084551\&Location=U2\&doc=GetT RDoc.pdf (accessed August 8, 2012).

25. Dreyfus, H. and Dreyfus S. (1986). Mind over Machine: The Power of Human Intuition and Expertise in the Era of the Computer. New York: Free Press. 
26. Ford, Ch. (1999). Lies! Lies! Lies! The Psychology of Deceit. Washington. American Psychiatric Press Inc.

27. Galbraith, J. (1958). The Affluent Society. $\left(40^{\text {th }}\right.$ anniversary edition, updated and with a new introduction by the author, 1998). New York: Houghton Mifflin Co.

28. Georgescu-Roegen, N. (1975)."Energy and Economic Myths." Southern Economic Journal 41, no. 3 (January), pp. 347-381.

29. http://www.dipecodir.it/upload/file/Cecchi EEcoTurCa/1975 georgescuroegen energy and economic myths.pdf (accessed May 15, 2014).

30. Gustavsson, J., Cederberg, Ch., Sonesson, U., van Otterdijk, R., Meybeck, A. "Global Food Losses and Food Vaste: Extent, Causes and Prevention", http://fvm.dk/fil ead min/userupload/FVM.dk/Dokumenter/Lan dbrug/Indsatser/Madspild/FAOrapportmad spild.pdf (accessed May 13, 2014).

31. Hancock, P. (2009). Mind, Machine and Morality: Toward a Philosophy of HumanTechnology Symbiosis. Farnham, Burlington: Ashgate Publishing Limited.

32. Heraclitus of Ephesus, The G.W.T. Patrick translation,http://www.classicpersuasion.o $\mathrm{rg} / \mathrm{pw} / \mathrm{heraclitus/herpate.htm}$ (accessed August 3, 2012).

33. Heidegger, M. (1951). "Poetically Man Dwells". (Translated by Albert Hofstadter). In Martin Heidegger, Philosophical and Political Writings, (Edited by Manfred Stassen 2003). New York, London: The Continuum International Publishing Group Inc.

34. Heidegger, M. (1949). "The Question Concerning Technology". In Martin Heidegger, The Question Concerning Technology, and other Essays. (Translated and with an
Introduction by William Lovitt, 1982). New York: Harper Torchbooks.

35. http://en.wikipedia.org/wiki/Military\%E2\% 80\%93industrialcomplex (accessed May 10 2014).

36. http://www.fao.org/human-right-tofood/en/

37. (accessed May 10, 2014).

38. Husserl, E. (1936). The Crisis of European Sciences and Transcendental Phenomenology, (English translation and translator's Introduction by David Carr. 1970). Evanston: Northwestern University Press.

39. Illich, I. (1975). Limits to Medicine. Medical Nemesis: The Expropriation of Health. (With a new introduction by the author, 2010). London: Marion Boyars Publisher.

40. Illich, I. (1974). Medical Nemesis. (2002) Mexico,http://www.davidtinapple.com/illic h/nemesis.html (accessed December 12, 2011).

41. Izambert, J.-L. (30 septembre 2009). "Le capitalisme en crise a besoin d'un conflit militaire majeur", http://www.geostrategi e.com/1906/le-capitalisme-en-crise-abesoin-d\%E2\%80\%99unconflit-militairemajeur/ (accessed May 15, 2014).

42. Kahn, H. and Wiener, A. ( 1967). The Year 2000. A Framework of Speculation on the Next Thirty Years. New York, London: Macmillan.

43. Kurzweil, Ray. (2001). The Law of Accelerating Returns, http://www.kurzweilai.net/ the-law-of-accelerating-returns (accessed May 15, 2014).

44. Lafargue, J. (2011). Machines hostiles. Le Monde Diplomatique Juillet.

45. Lauxerois, J. (2010). "Kostas Axelos - L'exil, l'errance, le passage", http://revues.mshp 
arisnord.org/appareil/index.php?id=978

(accessed May 11, 2014).

46. Machiavelli, N. (1513). The Prince. (Edited and translated by Daniel Donno (1966)). New York: Bantam Dell, 1984.

47. McBride, W. (2001). From Yugoslav Praxis to Global Pathos: Anti-hegemonic Postpost-Marxist Essays. Lanham: Rowman \& Littlefield,

48. Oborne, P. (2007). The Triumph of the Political Class. London: Simon \& Schuster.

49. OED Compact Edition, G., p. 267, in http:// en.wikipedia.org/wiki/God\#cite note-7 (accessed August 3, 2012).

50. Oreskes, N. \& Conway, E. (2010). Merchants of Doubt; How a Handful of Scientists Obscured the Truth on Issues from Tobacco Smoke to Global Warning. New York: Bloomsbury Press.

51. Ortega y Gasset, J. (1948). An Interpretation of Universal History. (Translated by Mildred Adams, 1984). New York: W.W. Norton \& Company.

52. Owensby, J. (1994). Dilthey and the Narrative of History. Ithaca New York: Cornell University Press.

53. Parkinson, S. (2010), "Science and Technology: Making a Difference." SGR (Scientists for Global Responsibility), http://www.sgr. org.uk/sites/sgr.org.uk/files/Manchester-sc itech-difference.pdf (accessed November 10, 2011).

54. Pignarre, Ph. (2005), "Le moment est venu d'être modeste", http://agora2.org/collog ue/pses2005.nsf/Conferences/Lemomente stvenudetremodestePhilippePignarre (accessed December 10, 2011).

55. Popper, K. (1978). "Three Worlds". The Tanner Lecture on Human Values, http:// tannerlectures.utah.edu/lectures/docume nts/popper80.pdf (accessed August 7, 2012).

56. Postman, N. (2001). "Deus Machina". Technos Quarterly, Vol. 10 No. 1, (Spring) http: //www.ait.net/technos/tq 01/4postman.p hp (accessed February 16, 2012).

57. Rousseau, J.-J. (1750). "Discours qui a remporté le prix de l'Académie de Dijon; en I'année 1750; sur cette question, imposée par la même Académie: Si le rétablissement des sciences et des arts a contribué a épurer les mœurs". In: Rousseau, J. Oeuvres complètes, tome I. Paris: Firmin Didot frères, libraires, imprimeurs de l'Institut de France, 1866.

58. Sartre, J.-P. (1960). Critique de la raison dialectique. I. Questions de méthode. Paris: Gallimard.

59. SIPRhttp://www.sipri.org/research/armam e nts/milex/resultoutput/tren-ds (accessed October 7, 2011).

60. Vernant, J. (1965). Myth and Thought among the Greeks. (Translated by Janet Lloyd with Jeff Fort, 2006). New York: Zone Books.

61. Voltaire. "On The Lord Bacon." In: Letters on the English or Lettres Philosophiques. 1778, Letter XII, http://www.fordham.edu/ halsall/m od/1778voltaire-lettres.asp\#Lett er\%20XII (accessed February 15, 2012).

62. Ziegler, J. (2011). Destruction massive. Géopolitique de la faim. Paris: Seuil.

63. Zizek, S. (2009). The Sublime Object of Ide ology. London; New York: Verso.

64. Zweig, S. (1942). The World of Yesterday: an autobiography. (Introduction by Harry Zohn, 1964). Lincoln and London: University of Nebraska Press. 


\section{FROM SLYNESS TO MORAL WISDOM IN THE ERA OF EMERGENT TECHNOLOGIES}

\section{SUMMARY}

The first aim of this paper is to circumscribe the concept of wisdom from the standpoint of opposite as well as close notions. The second one is to relate moral wisdom to social conditions; this aspect emphasises two states of moral wisdom or, rather, two levels on which the concept has been conceived: that of a fragmented and separated cognisance and manners to manage one's own existence - whether this entity is an individual person or a small or large community - and that of an integrated wisdom of humanity in a holistic approach.

The third aim of this research is to question if and how moral wisdom should be redefined in the present "Era of Emergent Technologies". Indeed, the abundance of rapid scientific discoveries and of technologies unimaginable before generates great expectations and strong technophile beliefs concerning a spectacular and fundamental improvement of human life, generally, thus of every human person and community. But as we can see, it is not quite the case: just this incongruent situation allows, more, requires the re-questioning of the concept of moral wisdom nowadays. This re-questioning shows that the different traditional representations of moral wisdom have to be transcended and that on the theoretical level the urgency is to think within new categories and support a new type of human action adequate to the world global problems whose climbing demonstrates the backwardness of moral wisdom.

Key concepts: wisdom, slyness, experience of life, science, emergent technologies.

FUQUY UUU

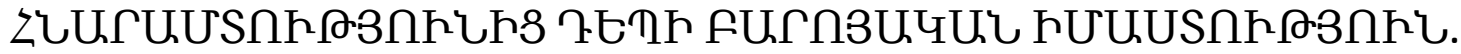

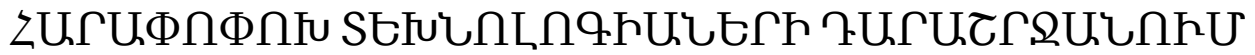

\section{Uし $\Phi \cap \Phi \cap h U$}

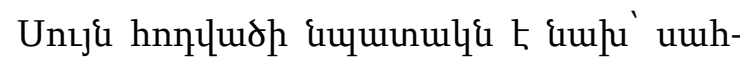

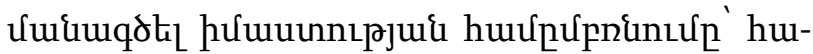

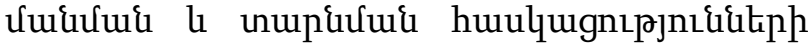

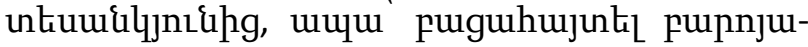

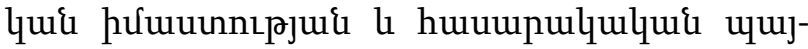

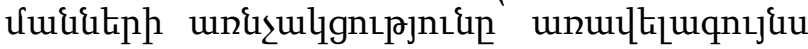

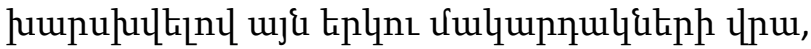

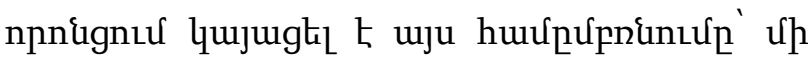

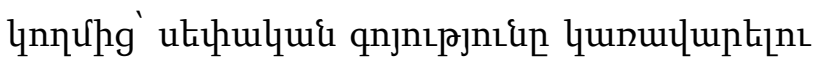

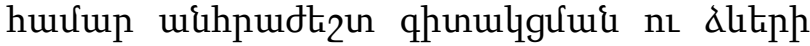

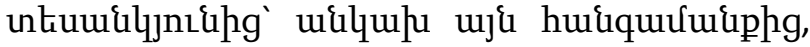

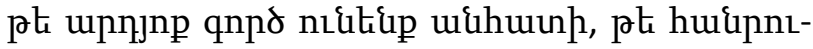

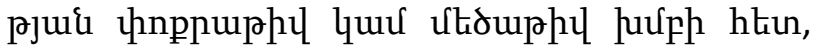

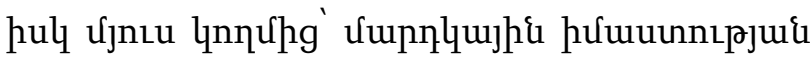

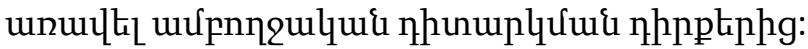


Ztinuqnunnıpjui \&uquinulqukphg tipnnp-

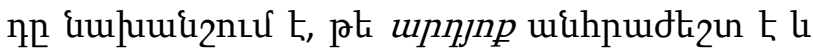

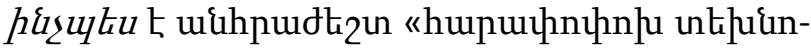

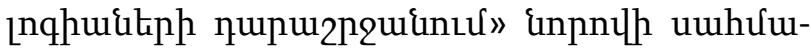

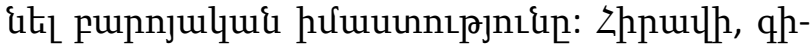

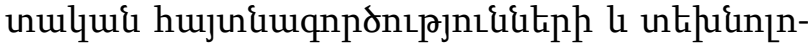

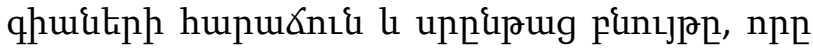

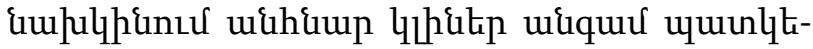

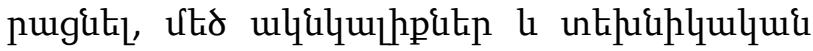

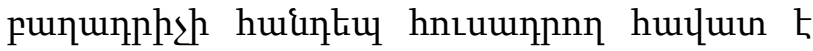
\{tip2

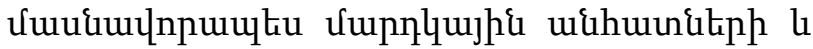

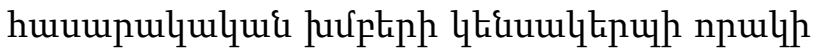

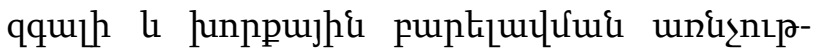

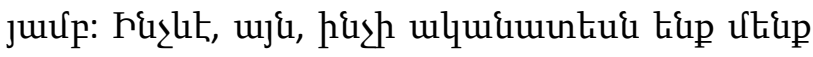

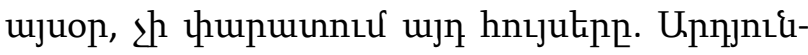

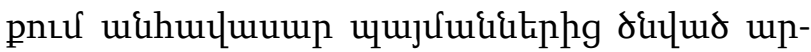

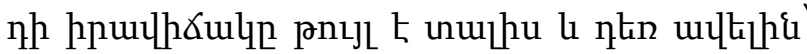

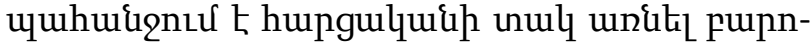

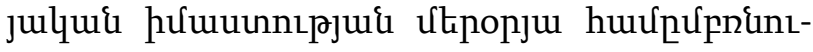

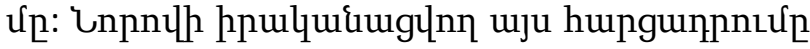
gnıjg Ł unußhu, np ujf ultinp Ł nnıpu płplh

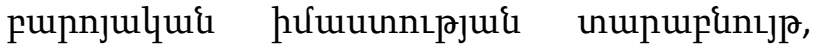

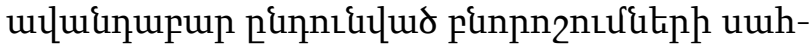

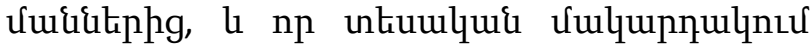

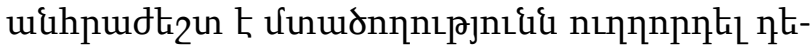
up inp lupqtiph unppnsjp, hul dupnluujhs

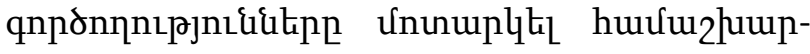

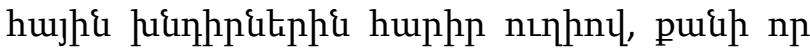
ujn hul halnhpitiph uhuqquagnn thitipn

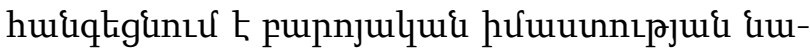
huiqhi:

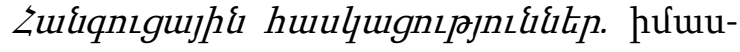

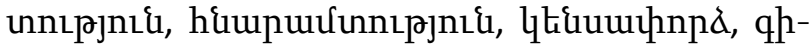

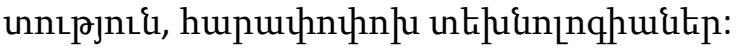

БАЗАК AHA

\section{ОТ НАХОДЧИВОСТИ К МОРАЛЬНОЙ МУДРОСТИ В ЭПОХУ НОВЕЙШИХ ТЕХНОЛОГИЙ}

\section{PEЗЮME}

Первая цель данной статьи - описать понятие мудрости с точки зрения противоположных и наиболее близких терминов. Вторая цель заключается в том, чтобы связать моральную мудрость с социальными условиями; этот аспект подчёркивает два состояния моральной мудрости, или точнее, два уровня, на котором это понятие было понято: как фрагментированного и разделённого знания и способов управления своим собственным существованием - будь то отдельная личность или малаое или большое сообщество, либо как интегральная мудрость человечества в её холлистическом представлении.
Третьей целью данного исследования является проблема если и как моральная мудрость должна быть переопределена в настоящую «Эпоху Новейших Технологий». Действительно, изобилие быстро растущего потока научных окрытий и технологий, что раньше было невообразимо, сегодня порождает большие ожидания и сильные технофильные убеждения относительно возможности поразительного и лоренного улучшения человеческой жизни вообще, в том числе и каждой человеческой личности и обществ в целом. Однко, как мы можем видеть, этого нет в реальности: именно неконгруентная 
ситуация позволяет, более того, требует заново поставить вопрос о понятии моральной мудрости в наши дни. Этот повторное исследование проблемы показывает, что различные традиционные представления о моральной мудрости должны быть преодолены и что на теоретическом уровне злободневно мыслить в рамках новых категорий и поддержать новый тип челове- чекой деятельности, адекватный глобальным проблемам современного мира, возрастание которых демонстрирует отставание моральной мудрости от современной жизни.

Ключевые понятия: мудрость, лукавство, жизненный опыт, наука, новейшие технологии. 